\title{
Meninos e Meninas na Rua Eles Fazem o Que Sabem, Mas não Sabem
}

O objetivo do trabalho é interrogar a psicanálise sobre o tipo de saber de Meninos e Meninas com experiência de rua, do Programa Miguilim da Prefeitura de Belo Horizonte, procurando formalizar uma experiência de supervisão psicanalítica ${ }^{1}$ da escuta dos educadores sociais e de outros profissionais integrantes desse Programa.

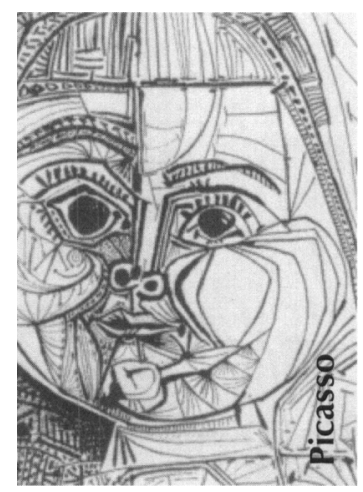

Nilza Rocha Féres

Psiconolista, Psicólogo. ex- protessora Adjunto do UFMG, escreve no colung "Em Dia Com a Psicanólise" do Jornat Estado de Minas.

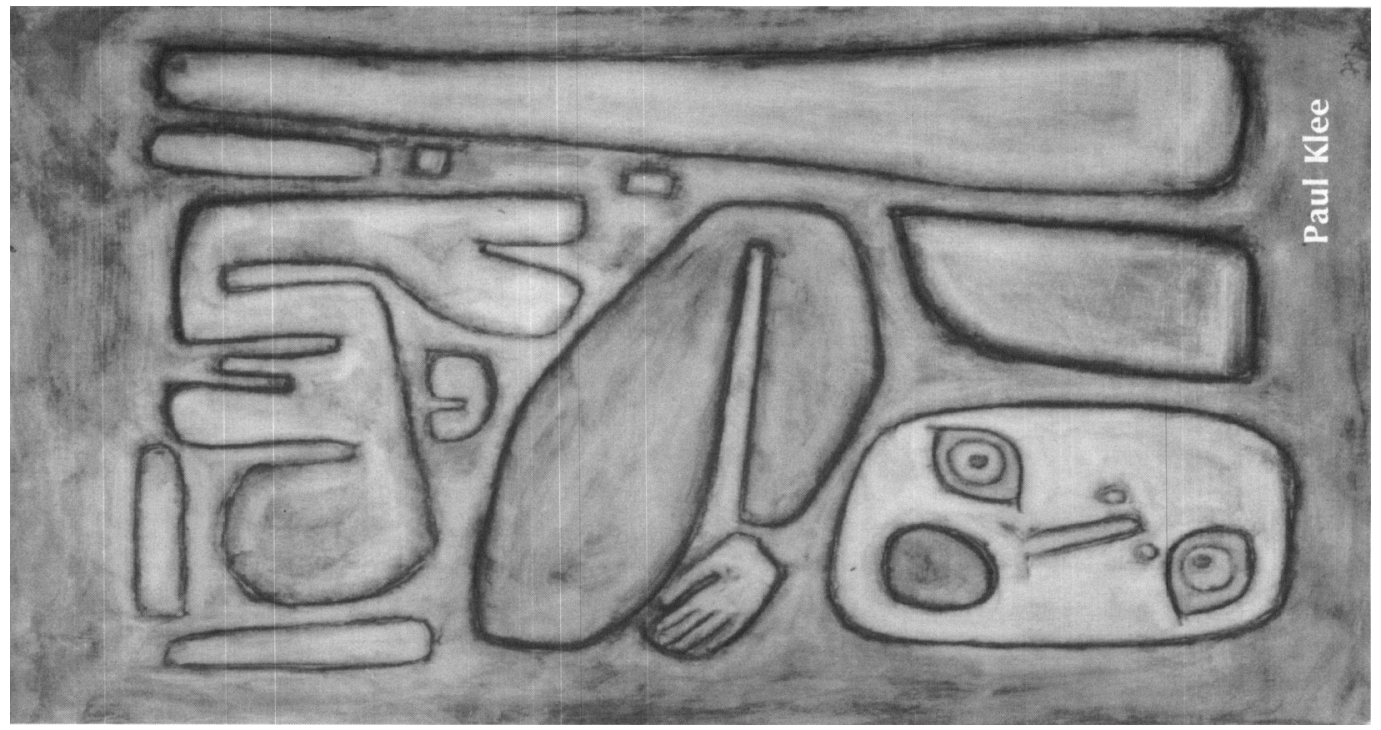

Meninos e Meninas na Rua passou a ser um significante que circula entre nós trazendo efeitos de significação, e até marcando um saber no Brasil sobre a habilidade em lidar com este novo fenômeno social, frente a comunidades estrangeiras sensibilizadas pelo tema, as quais enviam recursos e mesmo profissionais interessados na solução do problema. Como o nome o diz, são crianças e adolescentes que, não possuindo casa, lar ou família constituída, ou mesmo por outros motivos, passam a maior parte do tempo nas ruas, podendo mesmo habitar nas ruas da cidade ${ }^{2}$. Sabemos que há uma série de programas e instituiçōes governamentais e nâo-governamentais que fazem atendimento a este tipo de população, com o objetivo de atender suas necessidades básicas de moradia, escola ou emprego e de integração à sociedade ${ }^{3}$. Tivemos oportunidade de atender, em supenvisão psicanálitica, coordenadores e educadores sociais, integrantes do Programa Miguilim, da Prefeitura de Belo Horizonte, que fazem atendimento a estas crianças e adolescentes. Ofato de a psicanálise ser convocada para responder a uma demanda do social, já traz uma questão, levando-nos a indagar: como tratar tal demanda? Dentre as várias questões que nos suscitaram a escuta que nos foi trazida por estes profissionais de formação variada psicólogos, psicanalistas, pedagogos, assistentes sociais, sociólogos, artistas e outras - que trabalham com estes jovens, naquele momento privilegiamos a do saber, indagando qual é o tipo de saber desses Meninos e Meninas e de que ordem seria o enodamento deste saber, considerando-se os registros Real, Simbólico e Imaginário tal como Lacan os concebe ${ }^{4}$. 


\section{Ideologia e Razão Cínica}

A definiçāo mais elementar da ideologia, nos diz Zizek ${ }^{5}$, é provavelmente a de Marx, o célebre "disso eles não sabem, mas o fazem", atribuindo à ideologia uma certa ingenuidade constitutiva, pois desconheceria suas condiçōes e pressuposiçōes efetivas, mostrando uma distância entre a consciência e o que se faz. Tal posiçāo, Peter Sloterdijk ${ }^{6}$ vai chamar de razāo cínica, defendendo a tese de que a ideologia funciona cada vez mais dentro da fórmula: "Eles sabem muito bem $o$ que estão fazendo, mas mesmo assim o fazem". Assim, a razão cínica não é ingênua, tornando-se uma falsa consciência esclarecida, ou seja, está-se perfeitamente cônscio da falsidade, da particularidade por trás da universalidade ideológica, mas mesmo assim não renuncia a tal posição. Significando que reconhece o interesse particular atrás da máscara ideológica mas não abre mão dela. a moral colocada a serviço da imoralidade: "A sabedoria cínica consiste em apreender a probidade como a mais rematada forma de desonestidade, a moral como a forma suprema de devassidāo e a verdade como a forma mais eficaz de mentira". Assim, diante do enriquecimento ilícito, do roubo, do assalto, a posiçāo cínica consiste em afirmar que o enriquecimento legítimo é um assalto mais eficaz do que $o$ assalto, e que tem ainda a proteçāo da lei, como a pergunta do personagem na Ópera Três Vinténs, de Brecht: "Que é o assalto de um banco comparado a uma fundaçăo de um banco?" A sabedoria da posição cínica consiste em anular a discordância e legitimar a distância entre sua prática e os princípios proclamados vigentes, sendo contrária à transgressão direta da lei, que poderia ter uma conotação ética. Seria da ordem da ideologia ou da razão cínica a produção do fenômeno e do saber dessas crianças e adolescentes?

\section{A Escuta e o Saber}

A escuta de relatos de atendimentos dessas crianças e adolescentes nos faz indagar onde situar este saber que vinha da escuta desses profissionais nos diversos encontros e convívio com estes jovens: nas ruas ${ }^{7}$, nos albergues, nas oficinas, nos postos de saúde. A posição do sujeito nas estruturas clínicas neurose,psicose e perversão - se dá sempre pela forma como cada um se situa frente ao Outro, tendo de produzir uma pergunta sobre o saber. Na neurose encontramos uma pergunta típica ao saber - a neurose obsessiva se incluindo no saber e a estrutura histérica excluindo-se do saber. Enquanto a psicose nāo tem pergunta porque há a certeza psicótica, na estrutura perversa vamos encontrar a posiçáo do que se coloca como tendo todo o saber sobre a sexualidade. Não encontramos em nenhuma dessas posiçôes a possibilidade de dizer que uma delas recobriria todo o saber de tais crianças e adolescentes, afirmando por exemplo, que se trata de perverso, neurótico ou psicótico, embora possamos observar, de certa maneira e em determinados momentos, traços dessas posições. Nosso objetivo não é dar um rótulo ou aplicar o um a um ao coletivo, não pretendendo fazer um diagnóstico nos moldes tradicionais, mesmo porque não nos demandaram uma análise, mas estamos utilizando aqui o que Alain Grosrichard ${ }^{8}$ chama psicanálise implicada. Esta opõe-se a uma psicanálise aplicada, ao uso de chaves interpretativas, onde não haveria implicação, mas ao invés disto toma-se cada situaçāo, um texto, um relato, uma obra de arte, um sintoma social, deixando-os falar, como em uma associação livre. Nossa proposta amplia a escuta, e daí talvez pudéssemos chamar esta experiência de Clínica Ampliada, Clínica do Social, onde estaria sempre presente uma intervenção e năo uma interpretaçăo, tal como nos propōe Célio Garcia ${ }^{9}$ :
1-Esta experiência foi realizado de 1993 a 1996 na Secretaria de Desenvolvimento Social. iuntamente com as colegas psicanalistas Elisa Arreguy e Maria Ines Lodi, a convite do então Secretario Dr. Célio de castro.

2-Ver nota h.I no final do taxto.

3-Ver nota n. 2 no final do texto.

4- Os registros-Real, Simbólico $e$ lmaginario - sāo o ponto de partida e uma constante na obra de Lacan, cuja concepcáo irá se modificar ao longo do tempo. transformando-sefinalmente $\mathrm{em}$ utha escrita, atraves do no Borromeu. Escrita diferente da escrita da ciencia, pois nāo apaga, mas inclui o Real - o impossivel - enodando-se como Simbólico - ofuro do saber, a fala - atraves da consistência do Imaginato. O no do real to corpo que entrelaça o real de sua existência e o simbólico e na sua imprevisibilidade - do real - faz surgir o sintoma, enquanto o imaginánio da imagem do corpo. faz a consistência no enadamento dos registros. O imaginario refere-se à relaçào dual. espelhando no outro a imagem de si. o simbolico introduz a ordem simbólica - pela linguagem - resse espaço, enquanto a real para Lacan será o que está sempre no mesmo lugar. "colado de sola do sapato". impossivel. Esses três registros correspondem aos três anéts do nó Borromedno. Ver RSI, Mais, Ainda, La Tercera - op.cti)

5-Zizek, Slavof. Eles nāo sabem o que fazem - O subtime objato da ideologia -. Rio de Janciro: Jorge Zahar, 1992 .

6- Sloterdijk, Peter Critique de la raison dialetique paris: Christian Bourgois Editeur. 1987 .

7. Ver nota n. 3 no final do texto.

8 - Grosrichard, Alain. Torquato Quatro com Rousseau - Uma Mentira Magnanima. Palestra no Instituto de Estudos Avangados da USP. in Folha de S. Paulo reportagem de Bemardo Carvalho, 1993.

9 - Garcia, cellio clinica do Social. Belo Horizonte: UFMG Editora, 1997. 
"Vamos tentar definir e propor o que seria uma clínica do social. De imediato a tentativa pretende reunir a acuidade da clínica, seu

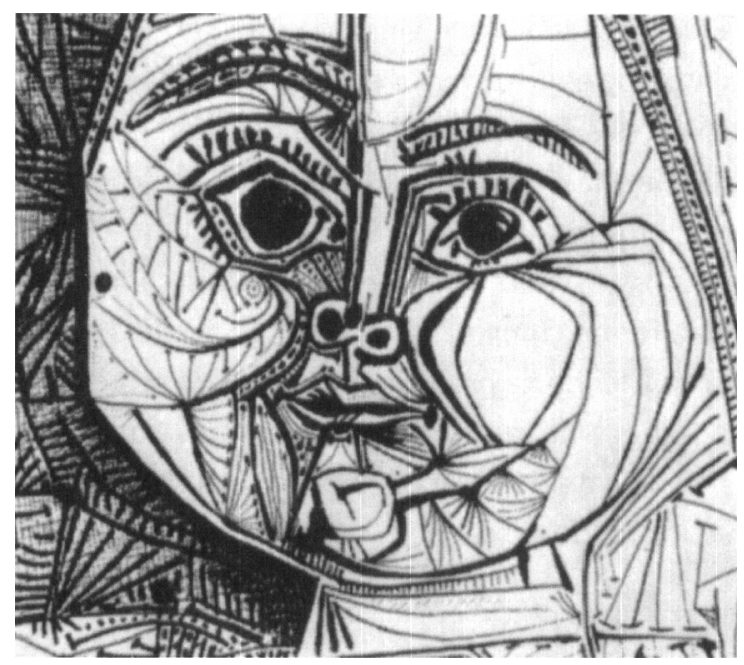

interesse, sua atenção voltados para a subjetividade de cada um, tudo isso aliado e articulado a um programa de ação politica como prática no dia-a-dia do cidadão.Para tanto, teriamos que contar com profissionais com alguma sensibilidade adquirida no atendimento clínico, sensibilidade forjada e afiada no trabalho de psicólogos, psicanalistas, assistentes sociais e demais trabalhadores sociais, sem deixar de lado experiência política eventualmente passada pelo crivo de revisões cruciais nesses últimos anos em função de redefinições da própria atividade de militante. Uma Clínica do Social me parece um referencial indispensável para educadores envolvidos em programas de atendimento a menores carentes como estes aqui denominados MMR."

Evidentemente que tal ampliação - a Clínica do Social- não elimina as questóes que continuam em debate entre a cultura e a clínica, mas lembrando que nem Freud nem Lacan recuaram frente a este tensionamento, pois ambos produziram importantes achados clínicos a partir de textos escritos. Como exemplo, lembramos a leitura de Freud ${ }^{10}$ do livro em que o juiz Schreber descreve sua doença, Memórias de um Doente dos
Nervos ${ }^{11}$, a partir da qual fez sua importante formalização teórica sobre a estrutura da paranóia e em Lacan ${ }^{12}$ temos o texto Kant com Sade, efeito de sua leitura sobre a obra do filósofo Kant e do escritor Sade, de onde extrairá uma clínica preciosíssima sobre a lógica da fantasia. Sobre o tema do social lembramos o que Freud ${ }^{13}$ escrevia em 1918, no Congresso de Budapeste:

"...é possivel prever que, mais cedo ou mais tarde, a consciência da sociedade despertará e lembrar-se-á de que o pobre tem exatamente tanto direito a uma assistência à sua mente, quanto o tem, agora, à ajuda oferecida pela cirurgia, e de que as neuroses ameaçam a saúde pública não menos do que a tuberculose, de que, como esta, também não podem ser deixadas aos cuidados impotentes de membros individuais da comunidade. Quando isto acontecer, haverá instituiçōes com clínica de pacientes externos, para as quais serão designados médicos analiticamente preparados, de modo que homens que de outra forma cederiam à bebida, mulheres que praticamente sucumbiriam a seu fardo de privações, crianças para as quais náo existem escolha a não ser o embrutecimento ou a neurose ${ }^{14}$, possam tornar-se capazes, pela análise, de resistência e de trabalho eficiente. Tais tratamentos serāogratuitos. Pode ser que passe um longo tempo antes que o Estado chegue a compreender como são urgentes estes deveres ou mais tarde, contudo, chegaremos a isso. Defrontar-nos-emos entào com a tarefa de adaptar nossas técnicas às novas condiçōes. (...)Precisamos buscar formas mais simples e mais facilmente inteligiveis de expressar as nossas doutrinas teóricas..."

Vemos, já no começo do século, o fundador da psicanálise indagando sobre o dever ético do psicanalista na sua prática e suas conexōes com o social. 


\section{O Saber é Sua Sobrevivência}

Voltando à comparação da posiçāo cínica, com a posiçāo dessas crianças e adolescentes, a hipótese é que haveria uma diferença entre as duas, da ordem de uma torçăo na consciência de saber, pois enquanto o cínico sabe e faz, tais crianças e adolescentes fazem o que sabem para sobreviver, pois por um pequeno deslize podem encontrar a morte, embora não saibam deste saber e menos do saber que não se sabe - do sujeito dividido, do inconsciente - enquanto na posição cínica se sabe exatamente o que se faz. Também não podemos dizer que são inocentes como preconiza Marx para a ideologia: eles não sabem o que fazem...E o que sabem e o que fazem estas crianças e adolescentes? De uma coisa estão certos: se nāo forem espertos, morrem. De que ordem seria tal tipo de saber? Na tentativa de uma localização inicial, diríamos que este saber da sobrevivência, estaria localizado no registro do Real - onde Lacan vai colocar a Vida ${ }^{15}$. Mas como para esses menores há uma fragilidade da mediação do Simbólico, onde se localizaria a morte, cada um responde com o corpo à urgência da imagem. Nesse registro do Imaginário, haveria uma negaçăo do medo da morte, que de certa maneira poderíamos tomar como a tendência a năo querer saber da castraçăo, como veremos a seguir.

Sobrevivem no desvio e deslizam furtivamente entre os ambulantes enquanto espreitam os bolsos, antes de derrubarem os seus donos. Ànoite se amontoam sob viadutos, procuram prédios abandonados, ou colocam seu pedaço de papelão em algum canto de onde - com sorte - são acordados pelo frio da manhã ou pelos pontapés da polícia. Na incerteza de suas vidas, cada acordar é sempre uma vitória ${ }^{16}$.

São muito espertos e sabidos, são capazes de ler bolsos e bolsas e rostos com a maior rapidez, sabendo o que e quanto contêm e o potencial de reação de seus portadores. $\mathrm{E}$ é $\mathrm{a}$ precisão desta leitura e dos outros sinais das ruas, o policiamento, as vias abertas ou fechadas que possam facilitar ou obstaculizar a fuga, que possibilitarāo o sucesso de suas açōes. Podemos dizer, portanto, que os MMR têm um saber sobre como ler os sinais nas ruas da cidade, o qual é responsável pela sua sobrevivência, exigindo-se que este saber seja utilizado da maneira mais rápida possível, pois a pressa e a urgência respondem a cada segundo pela vida ou pela morte, deixando de lado a urgência do sujeito ${ }^{17}$ que o faz colocar perguntas, enquanto a dessas crianças e adolescentes conduz à passagem ao ato. Se não se tem idéia das coordenadas de um sujeito, não se pode calcular onde ele cai ou surge. É preciso saber sua identidade, nome, endereço, discurso familiar.

Eles não têm este tempo da indagação, do vacilo, porque se este advém no meio da rua, eles morrem. E disto eles sabem também quando dizem que não têm nada a perder $\mathrm{e}$ que não têm medo da morte porque ela chega muito cedo para eles. Quase sempre, antes da maioridade. Esta urgência que faz uma constante passagem ao ato, opōe-se à dimensăo do inconsciente, fazendo uma ruptura aguda com o pensamento.

O olhar é de início o órgāo privilegiado, pois têm de medir e avaliar o trânsito, o corpo dos outros - das vítimas e da polícia e do seu próprio - para ver e perceber os objetos cobiçados e como se apossar dos mesmos e como se livrar dos perseguidores, seja correndo, escondendo-se, seja pegando carona na traseira de um ônibus que passa. $E$ tudo isto é muito rápido, porque a rua é rápida e uma fraçāo de segundo pode fazer fracassar a missăo e deixar-se cair nas garras da lei. Eé desta que se corre o tempo todo - às vezes até mesmo para cair em seus braços - valendo a frase: se correr o bicho pega e se ficar o bicho come. Diante destas duas opçōes eles correm e mudam de lugar o tempo todo, sem lenço, sem documento. E não é figura de
"Que é o assalto de um banco comparado a uma fundaçāo de um banco"? 
Enquanto isso, nossos meninos e meninas de rua treinam-se para a sobrevivência em um espaço que náo é seue do qual só podem ver restos $\theta$ pedaços.

18-Feres. Nitza Rocha. Etica e Lei.uma contribuiçào da psicanalise no tratamento dos Meninos e Meninas de Rua . In Alétheia. publicação do Inconsciente-Centro de Estudos Freudianos, n.2, 1998, p. 82.

19-Dimenstein, Giberto. Voce sabe a data de seu nascimentot in Fotha de S.Pauto de 21.07 .98 .

20.Ver nota n.4 no final do texto.

21 - Ver nota n. 5 no final do texto.

22 - Dietzsch, Mary fútia Martins. op. cit, p. 50 .

23 -Lacan, jacques. o eu na teoria de Fretude na téchica da psicanálise. O Semindrio -lino 2. Rio de laneiro: longe Zahar, p. 14. 1986.

24 -Subversion du sujet et dialectique du desir dans $l e$ inconsciente fretudien. Paris: Setul. 1966.

25 - Dietzsch, $M$ ary litia Martins. Op.cit., p. 50. linguagem, porque muitos deles não têm documento, não sabem seu nome, nem quem sāo os pais, nem o dia e onde nasceram. Tudo que têm, desde o apelido, receberam da rua, pois é certo que o ser falante encontre uma família que exerça o papel de nomeação em qualquer lugar, mesmo na selva ou na rua ${ }^{18}$. Pesquisa realizada pelo Cebrid em várias capitais mostra altas percentagens de MMR que nāo sabiam responder sobre a data de seu nascimento ${ }^{19}$, sendo que, em algumas capitais do Nordeste, mais da metade dos menores nāo sabia dar esta informação ${ }^{20}$.

Os educadores trabalham nas ruas e abordam esses menores em bandos - que é a forma mais comum de sua organizaçăo - ou individualmente. Quando não estão drogados, sabem exatamente o que dizer para agradar àqueles que os escutam, dizendo que o que mais desejam é ter uma casa, em geral, para morar com a mãe e a família, e um emprego e escola. Apresentam, assim, um outro lado dócil e até terno e sempre demandante - toda demanda é demanda de amor - que aparece quando ganham a confiança dos educadores, a quem chamam com toda intimidade de tiotia e a quem pedem tudo: casa, comida, emprego,roupas, documentos, amor.Mas a experiência mostra que ao se realizar este desejo, que se pode dizer, comum a todo cidadão, é aí que a singularidade aparece, pois é muito difícil para estes menores, que já fizeram da rua o seu lar (ver perfis, nota $n=3$ ), abandonar este espaço, freqüentar uma escola e dar seguimento a uma profissionalizaçấo ou ter uma assiduidade no emprego, pois estão sempre neste movimento de retorno à rua ${ }^{21}$. Esta passagem é muito difícil, tocando o impossível, porque o que a maioria deles procura é exatamente um novo líder ao qual poderiam se submeter, sem pensar, sem vacilar, como estão habituados.

Os programas que trabalham com esta população, teriam de dispor de um tempo tempo de compreender - para se fazer o tratamento desta demanda de submissão, facilitando esta passagem da lei da rua para a lei da cultura, inventando-se algo para que estas habilidades de sobrevivencia na rua pudessem transformar-se em novas competências para a obtenção de objetos da cultura. Daí a importância dos jogos, dos esportes, das leituras, das oficinas profissionalizantes e de arte, bem como experiência com o trabalho, que possibilitam e enfatizam as trocas simbólicas. Mas se os Programas também se colocarem no lugar do que sabe tudo que cada criança ou adolescente deve fazer para se tornar cidadão, haveria apenas mudança no nome do Mestre, mas o resultado seria o mesmo: a submissão à demanda do Outro.

A frustração às suas demandas é outro aspecto a ser considerado, pois quando nâo atendidos dentro de suas expectativas, apresentam as reaçōes de agressividade, negativismo e drogadicção.

Podemos dizer que essas crianças e adolescentes têm um saber privilegiado do corpo, do imaginário, enquanto a falha do simbólico os faz mergulhar nos enganos do imaginário, quando o real bruto da rua aparece sob as formas mais variadas de violência, pois o que não passou pelo simbólico reaparece sempre no real de uma forma desconhecida e brutal.E assim transitam pela cidade:

Sem levantarem os othos para alem dos bolsos dos transeuntes, os meninos se fixam e aprendem a ler os seus pés. Distinguem a crueldade do coturno e dele se escondem. Seguem o ritmo das sandálias dos sanfoneiros e com eles dançam. Se identificam com os pés descalços que passam voando e vêem neles um sinal de alerta. Acertam seus passos pelos pés dos grevistas e os acompanham em passeatas. Espreitam os passantes desavisados e com segurança adivinham os seus bolsos ${ }^{22}$.

\section{Eu é o Outro}

A famosa frase do poeta Rimbaud, "eu é um outro" foi utilizada por $\operatorname{Lacan}^{23}$ para mostrar esta debilidade estrutural do eu que se constitui a partir do outro - que podemos dizer tratar-se da mãe dos primeiros cuidados - do qual o eu, no início, é puro reflexo, e que dependerá de um terceiro termo, o Nomedo-Pai, para desprender-se dessa fixaçāo que seria mortífera. Diríamos de uma forma um 
pouco contundente, que estas crianças estariam fadadas a esta fixação ao Outro, a menos que uma outra intervençāo - da família, da escola, dos Programas, da Profissionalização ou mesmo da Clínica do Social - seja feita, possibilitando a entrada de uma lei pacificante.

Estes menores organizam-se em bandos, onde o que impera é a feroz e obscena lei de taliāo, olho por olho, dente por dente, valendo a vontade de gozo do chefe ou líder que se institui como o único que tem todo o saber $e$ o poder de gozo sobre as mulheres, nos moldes do mito do pai primevo relatado por Freud. $O$ chefe pode tudo, manda em tudo $e$ em todos. Por ele se rouba, e se praticam todas as violências, mesmo porque, cada criança ou adolescente está submetido de tal modo a este Outro, que impõe sua vontade cruel e mortífera da qual é muito difícil fugir, impedindo o sujeito de existir, no sentido de aceder a seu desejo. Pois este não pode aparecer, estando em posição de objeto para o outro, respondendo à demanda do Outro, mas inteiramente submetido a ele. Acreditando que o Outro existe, fazendo exigências imperativas para que cometam crimes e contravenções em busca dos objetos cobiçados por ele.

Lembremos da concepção de Lacan sobre o Outro como lugar do significante e que "todo enunciado de autoridade aí só tem como garantia sua própria enunciação, pois é inútil que o procure em um outro significante, o qual de modo algum não poderia aparecer fora desse lugar ${ }^{24}$." E a partir desta constatação conclui-se não haver metalinguagem, ou seja, não há uma palavra que vai dizer tudo, o que significa também que não há Outro do Outro. E podemos chamar de impostor, alguém que pretendesse se colocar neste lugar, como aquele que pretendesse erigir a Lei.Estas crianças e adolescentes têm uma dificuldade maior de estar nesta posição de que o desejo é o desejo do Outro, deste Outro ao qual falta um significante, deste Outro que não existe, mas que é necessário que seja constituído pelo próprio sujeito. Tornam-se, assim, presa fácil para se colocarem à mercê do semelhante que tomam como este Outro, que quer passar a ilusão de que nãoé barrado, ou seja, daquele que não quer saber que sempre faltará um significante, uma palavra que irá tudo dizer e trazer uma satisfação completa. Podemos dizer, também, que este semelhante-lider nada quer saber da

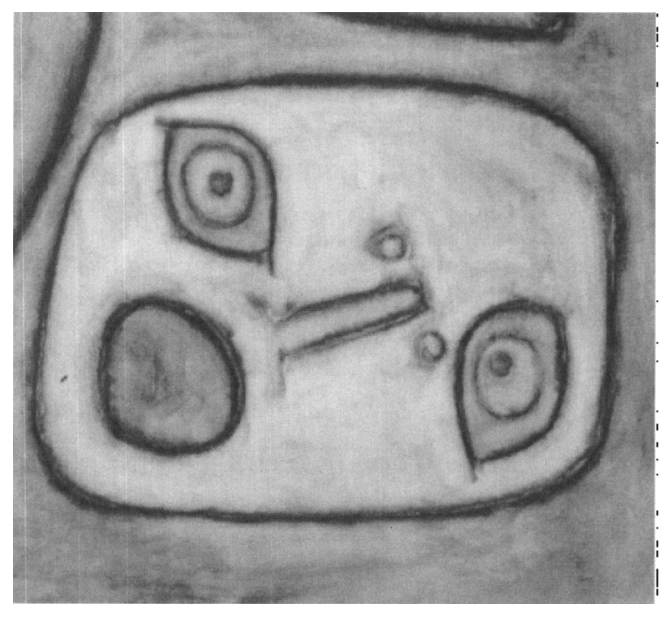

castração. É a este impostor que essas crianças e adolescentes se submetem, talvez fazendo dele, a marca de um ideal.

Submetendo-se ao imperativo do Outro, criança e objeto se fundem e se oferecem em sacrifício, pura vítima para seu gozo. Este papel de Outro não castrado, do qual esperase tudo saber, é exercido pelos líderes maiores ou pelos receptadores e mandantes que têm poderes de vida e morte sobre os menores. Diante desta realidade torna-se cada vez mais difícil para uma criança que vive sob esta lei, utilizar outras estratégias no uso do seu saber, a fim de encontrar outras formas de usufruir dos objetos da cultura, sem matar ou morrer.Pois, "Enquanto isso, nossos meninos e meninas de rua treinam-se para a sobrevivência em um espaço que não é seu e do qual só podern ver restos e pedaços. Transitam na planta baixa da cidade. Caminham e são forçados a othar em uma só direção, assim escondendo e sendo escondidos, da cidade năo vêem as projeçốes. Nāo atingem o

...enguanto o fatho do simbóllico os faz merguthar nos engonos do imaginário, quando o real bruto da rua aparece sob as formas mais variados de violencia, polso que nỡo passou pelo simbólico reaparece sempre no real de uma forma desconhecido e brutal 


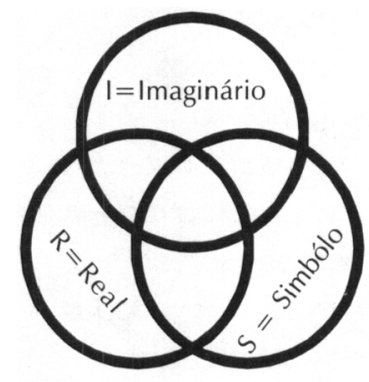

Fig .1 - Três ainda não é nada. Pois o verdadeiro problema, o problema geral, é fazer com que, com um número qualquer de rodinhas de barbante, quando vocês cortarem uma delas, todas as outras, sem exceção, estejam livres, independentes.

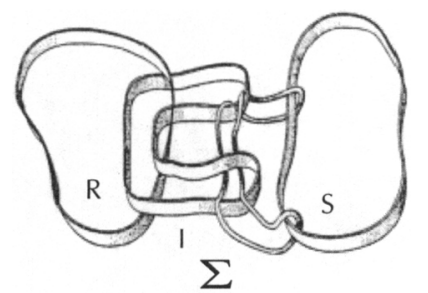

$\Sigma=$ Sintoma (4 ${ }^{\circ}$ nó)

$\mathrm{R}=$ Real

I=Imaginário

$\mathrm{S}=$ Simbólico

Fig. 2 - Aqui está o nó borromeano ano passado, já coloquei no quadronegro. É fácil vocês verem que duas rodinhas de barbante não são amarradas uma na outra, e que é unicamente pela terceira que elas se prendem. (Mais, ainda, p. 168)

( Scilicet, 516,p.39) espaço público em seus recortes. Não distinguem as perspectivas que se abrem para quem é e se comporta como um cidadão. Não enxergam e deixam de ser enxergados pelas Instituiçōes ${ }^{25}$."

\section{Os Nós}

Popularmente se diz que Menino em situação de rua dá nó até em pingo d'água, mas o que nos interessa saber é que tipo de nó é capaz de fazer em sua vida.

Lacan utilizou a teoria da matemática e da topologia dos nós ${ }^{26}$ para fazer a mostração diferentemente de uma demonstração - de como se relacionam os três registros do aparelho psíquico, formados pelo Real - o impossível de dizer, de escrever, o gozo, o imundo; o Simbólico - sistema significante que já é um corte ao gozo, e o Imaginário - onde se alojam o sentido, a imagem, a idéia e o pensamento. Formam-se vários tipos de nós conforme se faz a amarração de um registro com os outros, havendo um nó que poderíamos chamar o específico do humano, que é o borromeu. Este modelo foi tirado do brasão da família Borromeu (fig.1) que tinha este formato - três círculos que se enlaçam de maneira tal que se retirando ou cortandose um deles, todos os outros soltar-se-ão, desfazendo-se o nó. $\mathrm{E}$ é isto que significa a mostração, pois para se saber de que nó se trata, é necessário fazer o nó e cortar uma das argolas para ver se vai ou não mostrar esta propriedade de nó borromeu, ou seja, que todas as outras argolas ou registros cairāo. Se, ao contrário, após o corte, as argolas restantes permanecerem enodadas, significa que não se trata de um nó borromeu.

Este também é o funcionamento do psiquismo, se os três registros - Real, Imaginário e Simbólico - não estiverem enlaçados desta forma, podendo haver um curto-circuito que produzirá um disfuncionamento na amarração dos nós, soltando-se todos e trazendo conseqüências no relacionamento do sujeito com o mundo. No caso específico dessas crianças e adolescentes, o disfuncionamento poderia trazer esta impossibilidade de passarem da lei da rua para a lei da cultura, a menos que um outro tipo de amarração seja feito, através da intervenção do programa ou das instituiçōes. Se o nó borromeano é considerado o nó da estrutura do sujeito, como poderíamos utilizá-lo na formalizaçāo do saber destes jovens?

Nossa hipótese é que, na estrutura de enodamento do saber dessas crianças $e$ adolescentes, o Simbólico não se encontra enodado convenientemente com o Imaginário e o Real e supomos também que estes dois últimos se acham soldados um no outro, impedindo o pensamento, dificultando a intervenção do simbólico, que poderia fazer uma barragem à passagem ao ato. E quando isto ocorre significa que o nó do sujeito não está enodado borromeanamente, impondose uma suplência desta amarração, que deveria ser realizada pela intervenção de um quarto nó, que é um desdobramento do Simbólico, que equivaleria à função do Nomedo-Pai, que se apresenta defeituosa, na maioria dessas crianças.

O centro do nó borromeu, em torno do qual se organiza a satisfaçăo do sujeito, é um vazio, onde se localiza o objeto causa do desejo, ou seja, o que comanda toda sua vida. A amarração mais frouxa ou mais apertada vai ter conseqüências na maneira como o sujeito vai se colocar no mundo, com todos os objetos que o cercam. Este vazio assim deverá permanecer, pois nenhum objeto da experiência tem a propriedade de trazer uma satisfaçāo completa. Mas no enodamento dessas crianças, há a ilusão de que é possível encontrar este objeto, mesmo porque se colocam na posição de objeto. O seu saber convoca a certeza do objeto, e para esses jovens o objeto está lá, brilhando, chamando, exigindo ser apanhado. Existe o objeto, existe 
a relação sexual. Só o objeto conta, pois se o sujeito aparecer dividido será morte na certa. Não se pode vacilar. E disso eles sabem, e se colocam como objeto do gozo do Outro através do saber do corpo-objeto. Assim, o simbólico teria dificuldade de aí operar, pois o ato falho, o sintoma, os sonhos, seriam deslizes mortíferos. Há uma exigência de que não cometam erros, escapando, neste caso, da errância necessária da estrutura, onde o homem se torna humano em conseqüência de uma errância que é a linguagem, onde a palavra nāo diz exatamente o que se quer dizer. Fazer, errar, refazer o nó, é o destino do ser falante que insiste em continuar dizendo, errando, consertando, falando de novo, refazendo. Enquanto essas crianças e adolescentes, no lugar da palavra, fazem a passagem ao ato que as impede de pensar e falar, e de refazer seus nós e suas ações.

A Ronda, um ritual de vingança utilizado pelos líderes quando algum elemento transgride uma norma de seu grupo - não roubar ou ficar com o produto do roubo, namorar as mulheres do líder, delatar o que se passa no grupo -, exemplifica esta passagem ao ato de forma feroz e obscena. O ritual consiste em uma reunião em forma de círculo, onde, em geral, o grupo faz uso de drogas e a vítima é colocada no centro e sofre todas as sevícias possíveis e imaginadas pelos participantes. Estas podem ser de tortura, violência sexual, podendo chegar até a morte, indo além da máxima sadiana ${ }^{27}$ : "tenho direito de gozar de seu corpo, qualquer um pode me dizer, e este direito eu o exercerei sem que ninguém venha colocar limite ao prazer ou nas exaçōes que eu possa obter..." Dissemos que estão além da máxima, porque nesta aparece a divisāo do sujeito, neste "pode me dizer qualquer um", indicando que o Outro dividido está presente, enquanto na Ronda, somente os chefes têm este direito, como se para eles, não houvesse divisão ou limite.

O Simbólico deverá ficar convenientemente enodado com os outros registros, para que a lei seja instaurada, possibilitando as trocas simbólicas e o franqueamento da linguagem, podendo-se falar ao invés de se passar ao ato de violência. Lacan vai dar uma nova escrita à realidade psíquica de Freud, com o quarto nó (fig.2), que é um desdobramento do Simbólico ao qual se acrescenta o sintoma e que irá fazer a amarração dos três registros, fundamentais para a realidade psíquica.

Podemos considerar o quarto nó ${ }^{28}$, esta amarração onde o sintoma - que também equivale ao Nome-do-Pai - é a possibilidade que cada menino ou menina teria de tentar fazer um novo tipo de enodamento, uma possivel suplência do Nome-do-Pai, que aí estaria em falta, propiciado pela atuação e intervençōes dos Programas, das Instituiçōes, de educadores e psicanalistas. Fora do simbólico o saber se manifesta no real. Mas este saber no real deve ser tratado pelo simbólico, que normalmente priva o sujeito de um saber e funda a existência em um nãosaber, fazendo a interdição do gozo. O saber cai, com efeito, no furo do simbólico. Este furo, só poderá ser feito quando cada um puder enunciar a sua pergunta, a sua dúvida, o seu pensamento. Fora disto este saber estaria fadado ao ato desenfreado e acéfalo da urgência da pulsão, que traz consigo a violência. $O$ programa só poderia obter uma resposta diferente dessa, criando condiçôes para que essas crianças e adolescentes possam formular suas questōes e dúvidas sem a passagem ao ato, como expressava um deles: "Eu quero e ao mesmo tempo não quero sair da rua..." Posição que demonstra esta possibilidade de falar ao invés de passar ao ato, e de saber de um não-saber, abandonando este apego a esta ilusão de um saber completo.Contrariamente à posição de que "se errar, morre," a proposta da psicanálise é de escutar o sintoma, os erros, libertando assim o corpo falante para o desejo, verdade do sintoma, para que essas crianças ou adolescentes näo sejam eternos prisioneiros soltos nas ruas, correndo e tentando fugir da morte, sem saber que esta posiçāo em si se torna mortífera ${ }^{29}$.
26. Lacan, Jacques, R.S.l. Semintrio inédito - Mais, ainda. O seminário, livro $X X$. Rio de laneiro: Zahar, 1985, p. 160 .

27 Lacan, facyues. Kant avec Sadc - op. cit. p. 750.

28 - - - - - - -

Seminário, livo 20, Mais, ainda, op. cit. p. 160 .

29 . Fères, Nilza Racha Lei culpa e diretito - uma concribuiçāo da psicanalise. In Culpa - Aspectos psicanaliticos, culturais a religiosas. Säo Paulo: lluminuras 1998.

30 - Dietzsch. Mary Júlia Martins. Op. cit. p. 51 . 
31- Féres, Niza Rocha. Entrevista com Solal Rabinovitch. Jornal Estado de Minas. Belo Horizonte. 28.07.98. Instituto de Estudos Avançados da USP: in Folha de $S$. Paulo, reportagem de Bernardo Carvalho, 1993
E se, e somente se, a criança ou o adolescente colocar sua questăo - pelos erros ou sintoma é que se poderia a partir daí enunciar: Escrita no corpo desses meninos e meninas, uma historia a ser contada, recriada, escrita e mostrada nos diferentes planos da cidade-Espaço que, aliás, deveria ser oferecido a todo cidadão. Assim, vistas de corpo inteiro, talvez essas crianças excluídas pudessem olhar para o alto, tendo a chance de enxergar a cidade em suas mais diferentes dimensōes. Então, mais do que escorraçados leitores de bolsos, bolsas e passos, levantariam os olhos e aprenderiam a escrita da cidade na leitura das linguagens que se permitem ao cidadão ${ }^{30}$.
Sair ou não sair da rua não é a questão de cada uma dessas crianças e adolescentes, pois é o sujeito que está aí em questão, podendo aparecer em qualquer lugar, desde que se chame por ele, pois o dever ético dos programas é propiciar tal ato. Ética que deve incluir algo que permita a cada um fazer o seu enodamento dos três registros, para que - sujeito da falta possa aí advir, podendo separar-se deste significante alienante, Meninos e Meninas na Rua, mesmo que continue na rua.E isto só será possível a partir da escuta do sintoma, onde a Clínica do Social, uma psicanálise implicada, tome seu lugar, e possa ensinar aos MMR este saber que não se sabe que se sabe $^{31}$, o saber do inconsciente.
Notas 1.Estamos usando o conceito de Meninos e Meninas em situaçăo de rua no seu sentido amplo, independentemente dos motivos e do tempo que essas crianças e adblescentes permanţ̧am na rua, com oobjetivo de tornar tal conceito mais operacional no presente contexto Entretanto, pescuisas identificaram difenentes perfis nesta populaçăo com trajerória de rua. Pode-se identificar descle us que aí trabalham para a subssistência da famífia, passando por aqueles que habitam a rua por outros motinos que náo o econômico, até a populaçâao de risco, que pode ou näo possuir lanes e pais, mas esta-se iniciando em atvindades que podem levar à fixaçāo aos bandos e à nia. Tais atividades réferemse a pequenas contravencodes, furtos e comportamentos anti-sociais que normaimente têm a aprovaçâo dos bandos que estâo sob a égide da leida rua enăo dacultura Em um primeiro momento pode parecer estranho que essas crianças e adolescentes - concentrando-se a média de idade nas faxias de 12 a 18 anos, embora se distribuam tamberm, em menor número, em outras faxxas, variando de menos de um ano até mais de 27 - queiram morar na rua. fntretanto, não se pode esquecer que a satisfaçâo é algo de pessoal e intransferivel e que ultrapassa a quexăo social e exonönica Desta forma tem causado surpresa a algurs profissionais e politicos, o fato de que, ofertando-se às crianças e adolescentes de rua, moradia, escola e profissto, muitas delas desprezem tais ofertas, preferindo permanecer na rua. Pode-se afirmar que, em uma análise superficial, em alguns casos, estar e permanecer na rua pode trazer sofrimento, mas que, junto com este, há uma satisfaçăo em a permanecer. Por conseguinte, sair ou nảo sair da rua ultrapassa as questōer sociais e polfticas, envolvendo tamberm o desejo que toca a subjetividade de cada um. Desta forma, ao definimos os Meninos e Meninas em situaçâo de Rua como os que habitam a rua, significa apenas que estamos fazendo um recorte neste mar de varíveis, presentes ro probtema, e indican do que mais que variáveis economicas e sociajs, está presente nesta escolha uma ruptura dos laços com a familia e. consequientemente, uma ruptura no psiquismo. Ruptura que tentanemos mostrar que ocorre na amarraçāo dos (rès registros, Real, Simbólico e imaginário. Esta definiçąo tem tàmbém como objetivo: estreitar o espaço de atendimento amplo dos programas, identificando os que realmente estâo fixados na rua ou propensos a fazer dela a sua moradia. Isto näo significa que se abandone o restante da populaç̧̌̆, seja de risco ou com outras caracteristicas, implicando ar as familias, a escola e a sociedade, para que tais jovens possam voltar a seus lares, quando possivel, e nāo necessitem de cuidados institucionais, que sempre deixam seqŭelas.

2. Experiências com essas crianças e adolescentes têm levado programas como o Axé de Salvador - Bahia - e o como Miguilim de Belo Horizonte e outros - a uma produçâo de conhecimentos sobre as condiçóes de vida dessa populaçâo que aponta para a distinçăo de categorias de acordo com o bipo de relação que se estabelecce com a rua, podendo-se agrupát-fas en três tipos de perfis: - Os que não retomam para casa todos os dias - embora mantendo laços familiares e com a comunidade de origem, retomam ao lar uma ou duas vezes por semana, para kevar os ganhos auferidos pelo trabatho nas ruas, tendo perdido os vinculos com a escola formal, O5 que romperam ou têm fracos laços parentais - os motivos desta ruptura sáo, na maioria dos casos, resultantes de insustentáveis condiçōes de sobrevivência e da degradaçāo das relaçōes familiares. Estes transformam a na em seu habilat permanente, correspondendo ao grupo típico dos chamados meninos e meninas em situaçio de rua. Embora nestas irés categorias eles corram os riscos da exploraçâo e violência que vigoram no contexto da rua, há uma exacerbaçăo do risco pessoal e social na terceira categoria. $O$ enfraquecimento dos laços comos grupos de referéncia, keva-os em dineçāo ao bando, negicto pela lei da nua, mas que, dai por diante, se constituirá em sua familia, única proteção para a sobrevivência.Faz-se, assim, a travessia: de merino na ua para menine de rua, com esta, daípara frente, tomandose seu lar. Essa cravessja terá profundos efeitos em suas atitudes. comportamentos, linguagem e papeis sociais. fste foi o púbfico parao qual foi criado o Programa Miguilim. (Programa Criança Cidadă Publicaçăo do Projeto Miguilim - Secretaria Municipal de Desenvalvimento Social da Prefeitura de BH - 1996)

3. Conforme pesquisas e estudos da Universidade Federal de Minas Cerais-UFMG, en Convénio com a Lniversidade lohn Hopkins, sediada nos Estados Unidos, em 1992400 crianças viviam nas ruas de Belo Horizonte, passando para 600 em 1995, segundo dados do Programa Miguilim. Constatou-se também que a quantidade e o movimento destes dependem das estratégias de sobrevivência que estabejecem. como os deslocamentos para outras cidades ou dentro da própria 
cidade, como eferto da competiçâa entre os bandos, da açăo policial e dos atravessadores die mercadonias e produtos de furtos. A fixaçâoem alguns pontos, embora os bandos sejam sempre bransitórios, se baseia no acesso à água, à satíffaçăo das necessidades básicas de alimentaçăo, repousso, e cambém na exigéncia de nào serem identificados, para sua segurança e proteção. Para isto escolhem praças, casaröes abandonados, viadutos, portas de restaurantes e supermercados, proximidades de linhas de trem ou quarteinjes fechados. Eé nestes iugares que os educadores sociais do Programa os abordam pela primeira vez, com o objetivo de estabelecer um vinculo pedagógico e afetivo. Vinculo fundamental para a estruturaçäo de confiança para a reconstituiçăo da história de vida de cada um, levando à transformação de sua trajetoria, articulando-se os conteúdos pessoais, sociais e politicos. Este processo implica, além desta primeira abordagem, 0 processo de transiçăo e o momento de consolidaçâo do desentace com a rua, como refereñncia de moradia e de valores. O Poder Público, atraves deste Programa da Prefeitura, tem o papel de articulador das diversas linhas politicas, pedagógicas e metodológicas de atuaçâa, envolvendo a familia, a comunidade e a sociedade em geral. E assim garantir aos MMR o direito à cidadania, assegurando-thes condiçôes para a sustentaçâo da ruptura com a rua. Isto só será possivel a partir da construç̧ăo de um novo projeto de vida, possibilitando oportunidades de realizaçbes afetivas, educativas, culturais, socializadoras, profissionais e de moradia. Tais objetivos sảo implementados atravès de parcerias com outras Organizaçбes Governamentais e Näo-Governamentais.(Referência:Programa Miguilim).

4. No Programa Miguilim, quando o edecador aborda uma criança ou adolescente e constata que ele näo possui documentos, a primeira providéncia é de obté-los. E se ele năo tiver os documentos, no caso de nơo dispor de dados sobre sua identidade, ele receberá um nome e será registrado, conforme as exigências da lei. Ner com relação à importância deste ato o texto da neferêmcia bibliográfican. 18.)

5. Segundo Relatório do Programa Miguilim, de 1996, a rede atendia aproximadamente 500 crianças e adolescentes - distribuídos em albergues, casas de apoio, casas-liares, casas, moradias, repúblicas gerenciadas pelas ONGs e Prefeitura de $8 \mathrm{H}$, Deste total, 50 foram encamintados para a familia e 200 para aescola; 779 estảo vahalhando emempresas, assessorados pelo Programa, e 79 participam de oficinas profissionalizantes. $E$ de 150 o número dos que continuam na rua, organizados em bandos e gangs e náo foram atingidos pelas unidades de atendimento, năo tendo concluído o processo de abordagem.
Nilza Rocha Fúres

Rua Aimores, 1297/906/F. 031 273.3391

fax.335.6257/e-mail - ferestam@mkm.com.br
Assoun, P.L. \& Zarifopulos, M.(7994). La régle sociale et son au-dejà inconsciente. In Psychanalyse et pratiques sociales. Paris: Anthropos.

Bar-on A. (1997). Criminalising Survival: Images and Reality of Street Children. in foumal of Social Policy - The journal of the Social Poticy Association, London, part i, v. 25, jan.

Ferreira, T. (7993). Os meninose a na- Uma interpelaçâoà psicanálise. (Fascículol. Belo Horizonte: FAPEMIC.

Freud, A. \& Burlinghan, D. (1958). Meninos sem lar. Rio de laneiro: Fundo de Cuitura.

Comer da Costa, A. (1995). Pedagogia da presença. Belo Horizonte: Modus Faciendi.
Crant, f. (1993). The situation of children in Brazil. Exposiçžco do diretor executivo da UNICEF de 21.72.93, no National Press Club, Washington. DC. Release da UNICEF.

Jarry, A. (Org.) (1987), Le sujet et ta loi - la petite délinquance Approche juridique et psychanalytique: Collogue des 13 et 14 juin, Sorbonne. Paris: Érés.

Winnicott, D.W. (1967). Da pediatria à psicanálise. Rio de Janeiro Francisco Alves.

forge Zahar.

(1975). Acriancae oseumundo. Rio de laneino

Zaluar, A. (7994). Volencia, Grime Organizado e Ader: a tragédia brasileira e seus desafios. in Governabilidade, sistema politico e violência urbana. Rio de Janeiro: losé Olympio.
Referências bibliográficas 